\title{
MINIMUM DEPTH OF MILLING TO OBTAIN THE DESIRED SURFACE ROUGHNESS IN MULTI-LAYER MATERIALS
}

\author{
MINIMALNA GLOBINA FREZANJA ZA DOSEGO ŽELENE \\ HRAPAVOSTI POVRŠINE PRI VEČSLOJNIH MATERIALIH
}

\author{
Uroš Župerl1, Tomaž Irgolič̌ ${ }^{\mathbf{1}}$, Miha Kovačič ${ }^{1,3}$ \\ ${ }^{1}$ University of Maribor, Faculty of Mechanical Engineering, Smetanova 17, 2000 Maribor, Slovenia, \\ 2 Var d.o.o, Gornja Radgona, Slovenia \\ ${ }^{3}$ Štore Steel, Železarska cesta 3, 3220 Štore \\ Prejem rokopisa - received: 2019-10-31; sprejem za objavo - accepted for publication: 2019-07-12
}

doi:10.17222/mit.2019.263 \begin{abstract}
The machining of multi-layer metal materials is an important manufacturing activity in the sheet-metal-forming-tools industry.
The process to make these advanced and difficult-to-cut materials is laser engineered net shaping (LENS). It uses a laser to melt metal powders into structures layer by layer, based on a developed computer-aided design (CAD) model. Despite the very good achievements of laser cladding regarding surface roughness and surface corrugation, it is still necessary to after-machine the deposited layers by employing grinding processes. The grinding process is time consuming; therefore, in this research the grinding is replaced with end-milling. The first goal of this research was to determine the influence of the LENS process parameters on the resulting roughness of the produced surface. The second, main goal of this research was to determine the minimum required depth of milling that is needed to obtain the desired surface quality of N6 grades or better. Knowing the thickness of the deposited layer is fundamental for determining the minimum required depth of cutting. Therefore, software using cross-section metallographic images of deposited layers for measuring the layer thickness was developed. It is able to recognize the multi-layer bounds and measure the thickness of a separate compact layer with an error of $1.6 \%$. The research employs an artificial neural network (ANN) for predicting the produced surface roughness and the minimum required depth of milling during the machining of $16 \mathrm{MnCr} 5 / 316 \mathrm{~L}$ four-layered metal material with a ball-end mill. The experimental results demonstrate that this method can accurately predict the surface roughness with an average prediction error of $3.7 \%$.

Keywords: surface roughness, depth of milling, prediction, ANN, multi-layered metal material, layer thickness.
\end{abstract}

Obdelava več- slojnih kovinskih materialov z odrezovanjem je pomembna proizvodna dejavnost v industriji izdelave orodij za preoblikovanje pločevin. Ti napredni in težko obdelovalni materiali se izdelajo s postopkom laserskega nanašanja kovinskih slojev (LENS). Postopek uporabi laser za taljenje kovinskih praškov v strukturo sloj za slojem na podlagi izdelanega 3D modela. Kljub zelo dobri doseženi hrapavosti in valovitosti nakladane površine, je potrebno naložen sloj naknadno obdelati s postopkom brušenja. Postopek brušenja je zamuden, zato je v tej raziskavi brušenje nadomeščeno z oblikovnim frezanjem. Prvi cilj te raziskave je bil ugotoviti vpliv LENS procesnih parametrov na hrapavost proizvedene površine. Drugi glavni cilj raziskave je bil določiti najmanjšo potrebno aksialno globino frezanja, ki je potrebna za dosego N6 kvalitete površine. Za določitev minimalne potrebne globine rezanja je bistveno poznavanje debelin nakladanih slojev. Zato je bila razvita programska oprema, ki na osnovi metalografskih slik prerezov nakladanih slojev izmeri debelino sloja. Programska oprema zna prepoznati meje med sloji in izmeri debelino posameznega sloja z napako $1,6 \%$. V raziskavi je uporabljena umetna nevronsko mreža za modeliranje in napovedovanje proizvedene hrapavosti površine ter minimalne potrebne globine frezanja med obdelavo štiri-slojnega kovinskega materiala $16 \mathrm{MnCr} 5$ / 316L s krogelnim frezalom. Rezultati eksperimentiranja so potrdili, da lahko ta metoda natančno napoveduje hrapavost površine s povprečno napako napovedovanja $3,7 \%$.

Ključne besede: hrapavost površine, globina frezanja, napoved, nevronska mreža, slojeviti kovinski material, debelina sloja

\section{INTRODUCTION}

The laser-based deposition of difficult-to-machine metal materials with the Laser Engineered Net Shaping (LENS) process is becoming a widespread technique for the modification of forming tools engravings for the automotive industry. ${ }^{1}$ The LENS process uses a laser to melt and apply metal powders to an existing tool engraving layer after layer based on a computer-aided design (CAD) model. To prevent oxidation, the deposition process of metal materials is carried out in an argon-filled chamber. In the tool-making industry, combinations of multilayer materials made of nickel

*Corresponding author's e-mail:

uros.zuperl@um.si (Uroš Župerl) alloys, titanium alloys, cobalt-chromium alloys and stainless steel are most commonly used..$^{2-4}$ Ahn worked out prototype engravings of forming tools and plastic injection-moulding tools using laser deposition. ${ }^{5}$ It exposes the difficulty of achieving the desired surface quality of the engravings.

LENS is still a developing technology and optimal process parameters, such as laser power $P$ and cladding speed $c$ (speed of laser head) are usually determined based on a technologist's experience in order to produce the desired layer thickness.

The laser power $\mathrm{P}$ and the cladding speed $\mathrm{c}$ have an impact on the hardness $H V$ and thickness $d$ of the manufactured layer in a multi-layered metal material. 


\section{U. ŽUPERL et al.: MINIMUM DEPTH OF MILLING TO OBTAIN THE DESIRED SURFACE ROUGHNESS IN ...}

U. Zuperl, ${ }^{6}$ in his research, investigated the impact of lens parameters on the hardness and thickness of a manufactured $16 \mathrm{MnCr} 5 / 316 \mathrm{~L}$ four-layered metal material. Taberenro and Calleya published research in which they provide the optimal lens parameter settings to achieve the desired microstructure. ${ }^{7,8}$

Furthermore, the laser power and cladding speed are closely related to the surface quality of the deposited layer. They have a significant influence on the surface roughness produced during the manufacturing of these advanced materials. Therefore, there is a practical interest to investigate the impact of the LENS process parameters on the surface roughness of the manufactured layer. The first objective of this research was to analyse the influence of the LENS machine parameters on the resulting roughness of the produced surface. Using the results of the analysis, research employs an artificial neural network (ANN) to estimate the surface roughness produced with the LENS process. The ANN predictive capabilities are used to capture the highly nonlinear relationship between the LENS process parameters and the surface roughness. The surface-roughness prediction model merged with the minimum axial depth of the cutting predictions is presented in Section 2.

Many models have been developed to predict the surface roughness in milling. These include classic statistical approaches as well as fuzzy systems, ANNs and genetic algorithms. ${ }^{9-13}$ A few ANN and adaptive neural fuzzy inference (ANFIS) based surface-finish prediction models have been proposed, but no evidence of research efforts that attempts to model the surface roughness in the milling of the laser-based metal deposition (LBMD) materials has been found. ${ }^{14}$

Despite achieving a very good surface quality and surface corrugation during laser cladding, it is still inevitability to after-machine the deposited layers by employing grinding processes. However, a grinding process changes the microstructure due to a local increase of the heat input. The microstructure changes are reflected in the poor mechanical properties of the deposited layers. The grinding process is also time consuming; therefore, there is a practical interest in replacing the grinding process with the more efficient high-speed ball end-milling. Due to the inhomogeneous structure of the multilayered metal materials, the milling of these materials leads to undesirable effects, such as tool breakage, rapid cutting-tool wear and surface deterioration.

The challenge in the precise milling of laser-deposited metal layers is to determine the appropriate axial depth of the cutting according to the LENS process parameters in order to achieve the desired surface roughness of the corrected forming tool engravings.

Therefore, the second main goal of this research was to determine the minimum required axial depth of milling $A_{\mathrm{D} \text { min }}$, which is needed to obtain the desired surface quality of N6 grades or better. For this purpose, the ANN was trained in this research to estimate the $A_{\mathrm{D} \text { min }}$ based on the input LENS process parameters.

The minimum milling depth of cutting for each multi-layer workpiece is equal to the distance between the maximum and the lowest point of the surface profile. Especially in ball end-milling, knowing the thickness of the deposited layer is fundamental for the optimum axial depth of milling determination. The precise measurement of the deposited layer thickness would help to determine the $A_{\mathrm{D} \text { min }}$. Nowadays, the layer thickness of the multi-layered materials is measured manually, from the prepared metallographic microscopic images. This procedure is time consuming and laborious. Therefore, measurement software was developed to simplify this procedure. The developed software uses cross-section metallographic images of the deposited layers for the thickness measuring. Due to the encouraging test results, a graphical interface was also developed and embedded into the measurement software. There has been no published research on inspecting the layer thickness of multi-layered materials using visual measurement systems.

Recently, some optical measurement systems to inspect the surface roughness of the machined piece were developed. ${ }^{15}$ One system employs a machine-vision system to inspect the machined surface roughness. ${ }^{16}$ Another uses fibre-optics to measure the diffuseness in the reflected light from the surface. ${ }^{17}$ Coman in his research outlines the application of distance measuring with Matlab/Simulink. ${ }^{18}$ Jovanovič developed a measurement program and user interface in LabView for visual inspections with a commercial web camera. ${ }^{19}$ However, all the mentioned vision-based measuring systems are limited to the laboratory environment.

The rest of the paper is organized as follows. The model for estimating the produced surface roughness and minimum required depth of milling is presented in Section 2. The developed software for measuring the deposited layer thickness is described in the third section. The fourth section presents the experimental set-up and the results outlined in the fifth section. The conclusions are drawn in the final section.

\section{PREDICTIVE SURFACE ROUGHNESS AND MINIMUM REQUIRED DEPTH OF MILLING MODELLING}

The goal of this research is to develop a methodology for predicting the surface roughness average produced during the ball-end milling of four-layered metal materials and the minimum required depth of milling, which is needed to obtain the desired surface quality of the N6 grade (surface roughness of $0.8 \mu \mathrm{m}$ ). This section outlines the adaptation of the ANN topology to the surface roughness $R_{\mathrm{a}}$ and the minimum required depthof-milling prediction problem. To carry out the modelling of the surface roughness average and minimum 
required depth of milling, the popular, four-layer architecture of a feedforward neural network is used based on a back-propagation learning algorithm. The developed ANN has two input neurons for modelling: laser power $P$ and the cladding speed $c$. The number of hidden layers, the optimum number of neurons in the individual hidden layer and the training parameters were determined by simulations. The optimum ANN contains 4 and 3 neurons in hidden layers. The output from the ANN is the surface roughness average $R_{\mathrm{a}}$ and the minimum required depth of milling $A_{\mathrm{d} \text { min }}$. Therefore, two output neurons are necessary. The signals passed through the neurons in the hidden and output layers are transformed by an ArcTangent activation function. Figure 1 shows a detailed topology of the developed ANN-based prediction model with a basic flow chart for training/testing.

Four steps are required to develop an ANN-based model. In Step 1, the training and testing data sets were introduced to the ANN. Thirty scaled data points were utilized as the inputs and outputs to train the ANN. Table 1 presents a list of thirty data used for the training and testing of the ANN; $30 \%$ of these data (highlighted sets) were used for ANN testing to verify the accuracy of the predicted values.

The ANN topology, training parameters were defined in Step 2 with numerical simulations of 50 various networks. The ANN performances were evaluated using the two criteria: average percentage error (APE) and the number of training iterations. The obtained satisfactory network topology and training parameters are outlined in Figure 1.
In Step 3, the training and testing phase is performed. Twenty-one sets of experimental data are used to conduct the 350 iterations of training. The training of the ANN is stopped when the prediction error reaches its minimum within 350 training iterations.

After the ANN had been trained, it was applied to 9 additional input-output data pairs that were excluded from the training process. The predictions were compared to the measurements and the prediction errors were calculated. Finally, in the fourth step, the trained ANN is ready to predict the cutting forces.

\section{SOFTWARE FOR DEPOSITED-LAYER THICKNESS MEASURING}

In this section, software using cross-section metallographic images of the deposited layers for layer-thickness measuring is presented. In Matlab the developed software visually identifies the multi-layer's bounds and measures the thickness of a separate layer in the multi-layered workpiece where several layers of identical material are deposited on the substrate. The detailed algorithm of the automated measurement software is presented in Figure 2. It consists of three parts. The first part is responsible for image preparation and noise filtration. The second part finds edges of the analyzed layer in the metallographic image. The third part measures the distance between the found edges.

The measurement starts with image reading in jpg format from the memory. The resolution of the image must be $1200 \times 720$ pixels. Then the algorithm transfers the color image into a grayscale image with "rgb2gray"

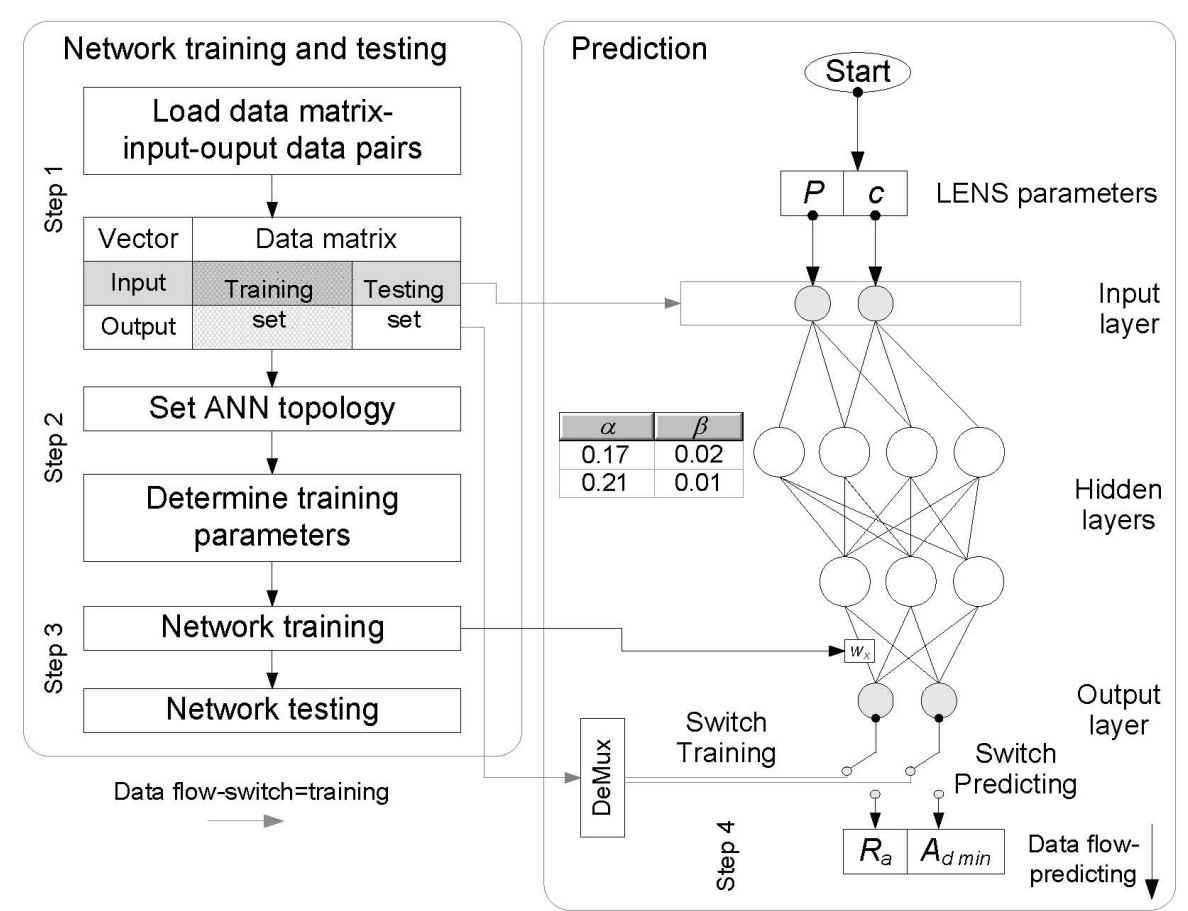

Figure 1: Structure and flow chart of training and employing the neural model for predicting surface roughness and minimal required depth of milling 


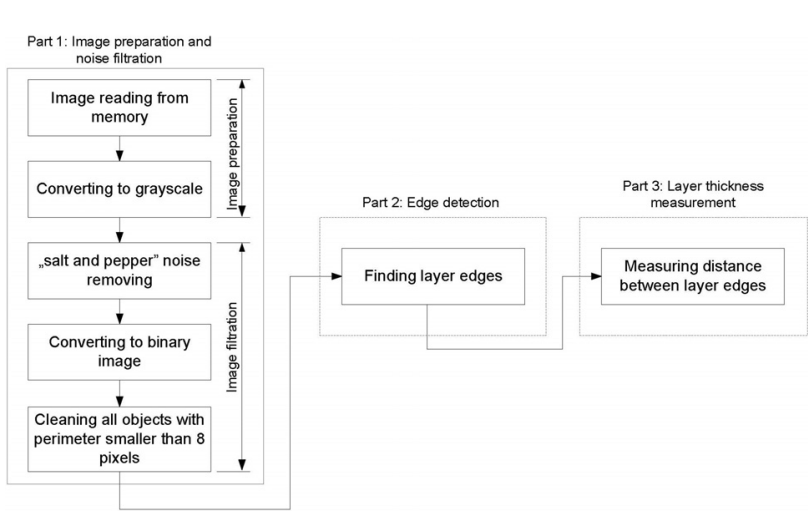

Figure 2: Algorithm of layer-thickness measurement

command (Figure 3). The image-filtration function is preformed with three transformation operations: noise removing, converting image to binary image and small pixel cleaning. Noise is removed with median filtering in two dimensions. After the noise reduction, the image is transferred to a binary image with the "graytresh" command. Next, the "im2bw" command substitutes all the pixels in the image with luminance greater than the computed threshold with the value " 1 " (white color). The objects form with perimeter smaller than 8 pixels are cleaned and extremes are removed with "strel('disk',8) and "imreconstruct" command during the image-filtration process. Through the above-mentioned steps, the image is prepared for edge detection. The command "edge" is used for this task.

During the edge detection, the algorithm finds the top and bottom edges (cell) the image matrix employing "max" and "min" command. The difference between the top and bottom edges is the layer thickness. This value is printed in the "Command Window" of Matlab. The thickness from pixels to micrometers is calculated by dividing the distance in pixels with the transformation ratio $k$, which is determined from the microscope measurement scale. The quotient between the distance in pixels and the distance in micrometres is the transformation ratio $k$. Figure 3 shows the above-outlined process of layer thickness measurement on the metallographic microscopic images.

For an intuitive measurement algorithm a Graphic User Interface (GUI) is developed. The Matlab "GUI

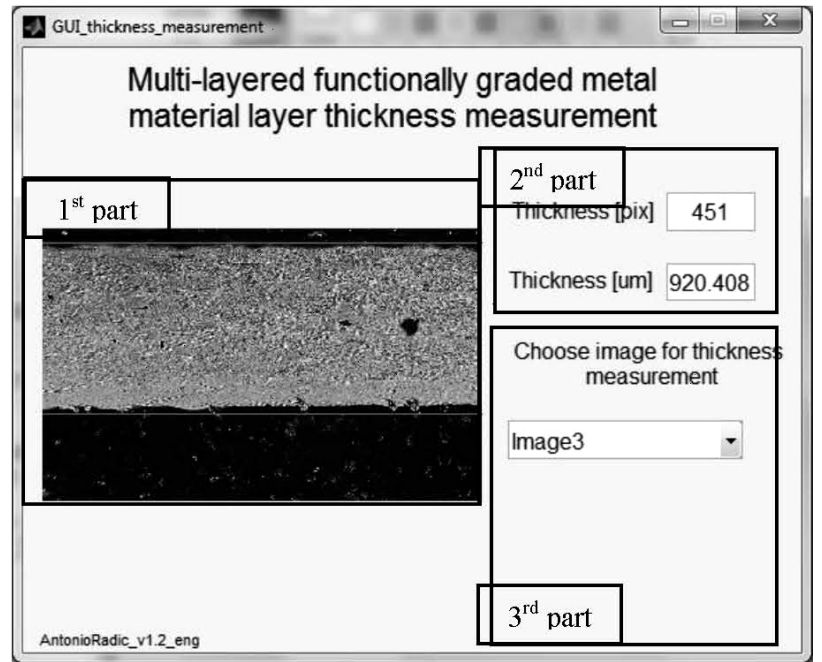

Figure 4: Graphical user interface with the layer thickness result for the LENS machine settings-cladding speed and laser power

Quick Start" is used for the creation of the Graphic User Interface (GUI). The developed GUI is shown in Figure 4. The GUI consists of three parts. The first part is located on the left-hand side of Figure 4. It shows the image that is measured. The layer thickness which is measured is marked with two parallel lines. The second part of the GUI is located in the upper right-hand side. This part shows the measured thickness, both in pixels and in micrometres. The third part of the GUI is a drop-down menu for selecting an image for the layerthickness measurement.

\section{EXPERIMENTAL PROCEDURE AND EQUIPMENT}

To build the ANN prediction model, experimental results were obtained according to the following procedure:

1. Thirty four-layered metal workpieces with different layer thicknesses were produced. LENS process parameters at $6 \times 5$ levels are outlined in Table 1 .

2. Thickness $d$ and surface roughness $R_{\mathrm{a}}$ of manufactured layers were measured.

3. The impact of the LENS process parameters on the $d$ of the manufactured layer was examined.
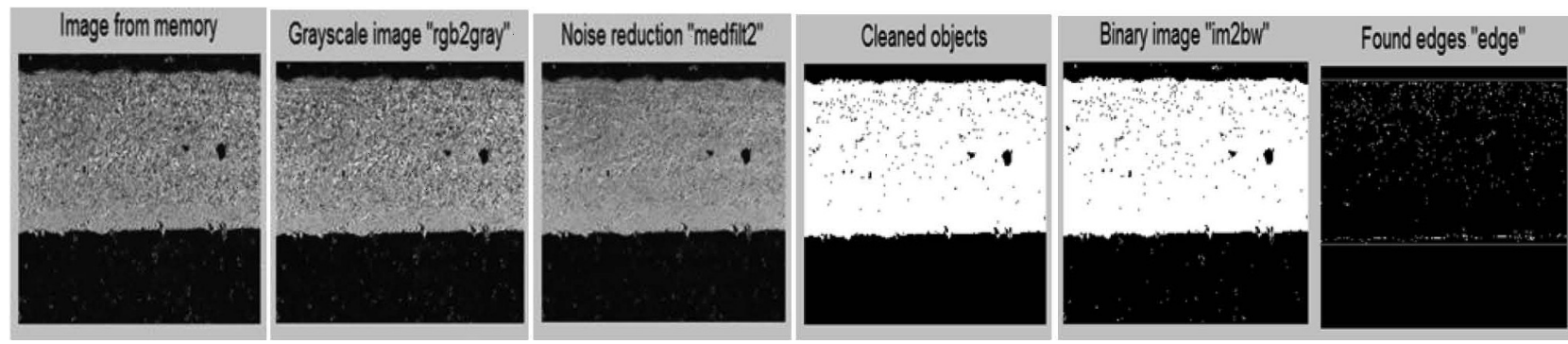

Figure 3: Procedure and result of layer-thickness measurement 
U. ŽUPERL et al.: MINIMUM DEPTH OF MILLING TO OBTAIN THE DESIRED SURFACE ROUGHNESS IN ...

Table 1: 30 datasets for training and testing of ANN; surface roughness and minimum required depth of milling predictions

\begin{tabular}{|c|c|c|c|c|c|c|c|c|c|c|c|c|c|}
\hline No. & $\begin{array}{c}P \\
(\mathrm{~W})\end{array}$ & $\begin{array}{c}c \\
(\mathrm{~mm} / \mathrm{s})\end{array}$ & $\begin{array}{l}A_{\mathrm{D} \text { min }} \\
(\mathrm{mm})\end{array}$ & $\begin{array}{c}R_{\mathrm{a}} \\
(\mu \mathrm{m})\end{array}$ & $\begin{array}{c}R_{\text {a }} \text { mea- } \\
\text { sured } \\
(\mu \mathrm{m})\end{array}$ & $\begin{array}{c}\text { Error } \\
(\%)\end{array}$ & No. & $\begin{array}{c}P \\
(\mathrm{~W})\end{array}$ & $\begin{array}{c}c \\
(\mathrm{~mm} / \mathrm{s})\end{array}$ & $\begin{array}{l}A_{\mathrm{D} \min } \\
(\mathrm{mm})\end{array}$ & $\begin{array}{c}R_{\mathrm{a}} \\
(\mu \mathrm{m})\end{array}$ & $\begin{array}{c}R_{\mathrm{a}} \text { mea- } \\
\text { sured } \\
(\mu \mathrm{m})\end{array}$ & $\begin{array}{c}\text { Error } \\
(\%)\end{array}$ \\
\hline 1 & 300 & 30 & 0.22 & 34.9 & 33.2 & 3.10 & 16 & 360 & 30 & 0.32 & 29.4 & 28.1 & 4.56 \\
\hline 2 & 300 & 38 & 0.30 & 33.9 & 32.9 & 3.06 & 17 & 360 & 38 & 0.39 & 29.0 & 27.9 & 3.86 \\
\hline 3 & 300 & 48 & 0.34 & 33.3 & 31.3 & 6.39 & 18 & 360 & 48 & 0.42 & 28.2 & 27.2 & 3.56 \\
\hline 4 & 300 & 55 & 0.42 & 30.2 & 29.2 & 3.59 & 19 & 360 & 55 & 0.55 & 26.9 & 25.2 & 6.92 \\
\hline 5 & 300 & 60 & 0.87 & 30.7 & 28.9 & 6.06 & 20 & 360 & 60 & 0.70 & 26.8 & 24.8 & 8.00 \\
\hline 6 & 320 & 30 & 0.27 & 32.3 & 31.3 & 3.07 & 21 & 380 & 30 & 0.30 & 27.0 & 26.2 & 3.16 \\
\hline 7 & 320 & 38 & 0.32 & 31.6 & 30.7 & 2.92 & 22 & 380 & 38 & 0.37 & 27.6 & 25.8 & 6.90 \\
\hline 8 & 320 & 48 & 0.36 & 30.4 & 29.1 & 4.47 & 23 & 380 & 48 & 0.23 & 26.6 & 25.6 & 4.01 \\
\hline 9 & 320 & 55 & 0.39 & 28.8 & 27.8 & 3.71 & 24 & 380 & 55 & 0.50 & 23.7 & 23.2 & 2.29 \\
\hline 10 & 320 & 60 & 0.89 & 27.2 & 26.8 & 1.64 & 25 & 380 & 60 & 0.70 & 24.2 & 22.8 & 5.98 \\
\hline 11 & 340 & 30 & 0.28 & 30.2 & 29.7 & 1.57 & 26 & 400 & 30 & 0.22 & 25.6 & 24.2 & 5.96 \\
\hline 12 & 340 & 38 & 0.34 & 29.0 & 28.6 & 1.50 & 27 & 400 & 38 & 0.25 & 24.4 & 23.9 & 2.08 \\
\hline 13 & 340 & 48 & 0.39 & 28.8 & 27.3 & 5.53 & 28 & 400 & 48 & 0.26 & 23.4 & 22.5 & 3.84 \\
\hline 14 & 340 & 55 & 0.39 & 27.4 & 25.8 & 6.31 & 29 & 400 & 55 & 0.46 & 23.2 & 22.1 & 5.02 \\
\hline \multirow[t]{2}{*}{15} & 340 & 60 & 0.87 & 25.3 & 24.2 & 4.49 & 30 & 400 & 60 & 0.51 & 22.4 & 21.6 & 3.70 \\
\hline & & & & & & & & & & & & APE $(\%)$ & 3.70 \\
\hline
\end{tabular}

4. The minimal required axial cutting depth $A_{\mathrm{D} \text { min }}$ for each test workpiece was determined form the surface-roughness profile.

5. Machining tests were carried out to obtain the desired surface quality of N6 grades or better

6. The results of the measured surface roughness after machining were stored for future analyses.

The machining experiments were carried out on the CNC milling machine (type HELLER BEA01), under dry cutting conditions. The surface roughness was measured using a 7061 MarSurf PS1 Surface Roughness Tester. In the measurements of contact stylus instrument, an 80 -mm stylus arm length, a 2 - $\mu \mathrm{m}$-radius conisphere diamond stylus tip size, a 5.6-mm traversing length, a 4-mm measuring (evaluation) length and a $0.7-\mathrm{mN}$ measuring force $($ speed $=1 \mathrm{~mm} / \mathrm{s}$ ) were used. The profilometer has an $18-\mathrm{nm}$ resolution at $0.18 \mathrm{~mm}$ and an 8 - $\mathrm{nm}$ resolution at $0.09 \mathrm{~mm}$ vertical range. The arithmetic average of the absolute values of roughness profile was determined by means of the phase-correct profile filter (Gaussian filter; ISO 11562) with $0.8 \mathrm{~mm}$ cut-off wavelength value and $4 \mathrm{~L}$ access length of the tactile profilometer. The profilometer scanned $4 \mathrm{~mm}$ in length. Three fixed spots on each surface, one in the middle and the other two on the edge, were used to measure the surface roughness.

The solid ball-end milling cutting tools (Tornado) of $8 \mathrm{~mm}$ diameter with two cutting edges, of $29.9^{\circ}$ helix angle and $2.28^{\circ}$ rake angle, were used. The ball-end mills were made of a sintered tungsten carbide material K88UF with the hardness of $1770 \mathrm{HV}$. The following values for the spindle speed and the feed rate were selected: $n=3000 \mathrm{~min}^{-1}, f=200 \mathrm{~mm} / \mathrm{min}$.

The workpiece material is made of a $16 \mathrm{MnCr} 5$ basic material and four stainless-steel (316L) layers with a singular $0.3 \mathrm{~mm}$ to $1.0 \mathrm{~mm}$ thickness, length of $50 \mathrm{~mm}$ and width of $15 \mathrm{~mm}$. Thirty such belts of stainless-steel layers were cladded on a singular workpiece with a $60-\mathrm{mm}$ thickness, length of $180 \mathrm{~mm}$ and width of 70 $\mathrm{mm}$. By varying the two LENS process parameters, 30

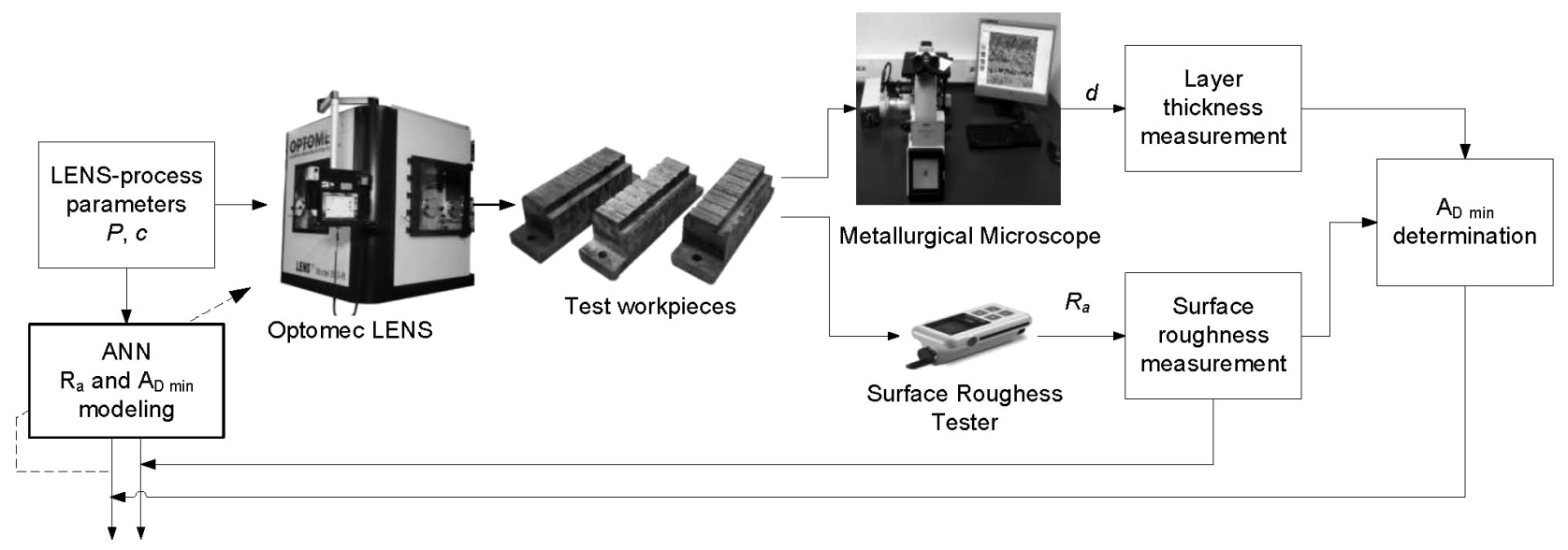

Figure 5: Experimental set-up 


\section{U. ŽUPERL et al.: MINIMUM DEPTH OF MILLING TO OBTAIN THE DESIRED SURFACE ROUGHNESS IN ...}

different test workpieces (30 tests) of the four-layered metal material with different layer hardness and thickness were produced on the Optomec LENS 850-R machine. The overlapping in all layers was set to $40 \%$. The diameter of the laser ray was $0.8 \mathrm{~mm}$. The experimental setup can be seen in Figure 5. The layer thicknesses $d$ of the manufactured metal material were measured with a Nikon Epiphot 300 Inverted Metallurgical Microscope.

\section{RESULTS}

Several experimental tests were performed in order to validate the ANN model for different LENS machine parameters. A criterion in these tests used to judge the efficiency of the ANN prediction model was the average percentage error (APE).

Table 1 lists the input and output of the prediction model results for the LENS parameters, minimal required depth of milling and surface roughness.

The results that were obtained from the 30 tests performed on the LENS machine are also presented in Figure 6. One plot has been worked out to determine the variation of two LENS parameters with respect to the course of $A_{\mathrm{D} \text { min }}$.

In this paper, the result of the layer thickness measurement algorithm was outlined for one metallographic microscopic image, which is shown on the left-hand side in Figure 3. This image is the input to the distance measurement software. Measured thickness d by using the developed algorithm equals $889.5 \mu \mathrm{m}$.

\section{DISCUSSION}

The input and output of the prediction model results for the LENS parameters, minimal required depth of milling and surface roughness are given in Table $\mathbf{1}$. Table 1 compares the experimental data and the predicted values of $R_{\mathrm{a}}$ after the training of the ANN model. The predicted values are very close to the experimental measurement values. The results mutually differ from

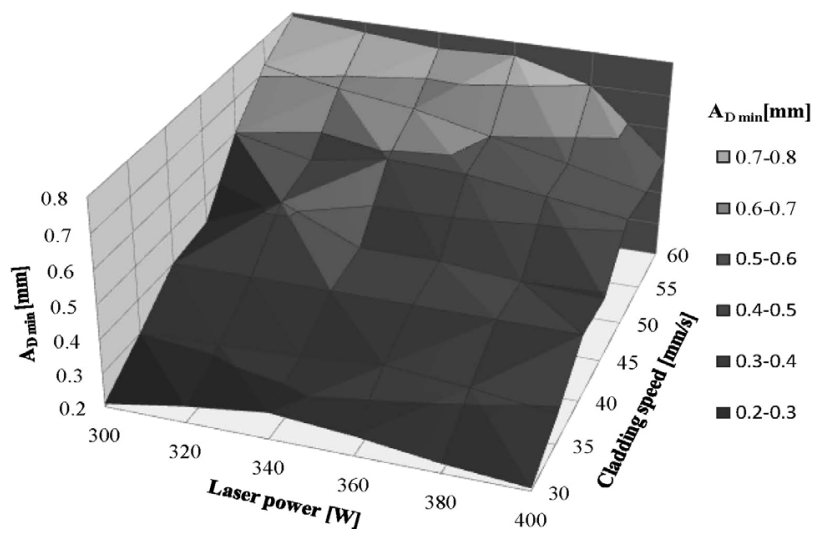

Figure 6: Impact of LENS parameters on the minimal required depth of milling $A_{\mathrm{D}}$ min
$1.5 \%$ to $8 \%$ for all the cases tested. The average percentage prediction surface roughness error (APE) is found to be $3.7 \%$. The results in Table 1 show that the ANN model provides good agreement with experimental results.

In the experiments, it was found that the cladding speed has the largest impact on the minimal required depth of cutting $A_{\mathrm{D} \text { min }}$ when attaining the desired surface quality of the machined surface. Figure 6 shows that the $A_{\mathrm{D}}$ min decreases linearly when the cladding speed increases. Figure 6 indicates that the minimal required depth of cutting $A_{\mathrm{D} \text { min }}$ increases from $0.22 \mathrm{~mm}$ to $0.78 \mathrm{~mm}$ when the c increases from $30 \mathrm{~mm} / \mathrm{s}$ to $60 \mathrm{~mm} / \mathrm{s}$ at the constant laser power of $300 \mathrm{~W}$. It can be concluded that the maximum axial milling depth required to achieve the desired surface roughness was in the region where the thicknesses of the deposited layers were the greatest; this is in the area of minimum laser power and maximum cladding speed.

A test workpiece with a determined thickness of $920.4 \mu \mathrm{m}$ is shown in Figure 4. The LENS machine settings for this test workpiece were: $60 \mathrm{~mm} / \mathrm{s}$; laser power: $360 \mathrm{~W}$. The real thickness of the analysed layer is $912.3 \mu \mathrm{m}$. This gives a measurement error of $0.9 \%$. For all the other cases, not included in this paper, the error depends on the layer structure and is $2.6 \%$ for the compact layers and up to $9.8 \%$ for the less compact layers.

The distance measurement software needs approximately 0.5 second to complete the measurement of the thickness of one deposited layer. The developed software is able to recognize the multi-layers' bounds and measure the thickness of a separate layer in the multi-layered workpiece where several layers of identical material are deposited on the substrate. The software requires 1 second to determine the distances between the four-layer bounds in the four-layered material. Therefore, the measurement process is fast once the initial metallographic microscopic images are available in a JPEG file format.

\section{CONCLUSIONS}

The main focus of this research is to develop a reliable method to predict the surface roughness of manufactured multi-layered metal material and the minimal required axial depth of milling for obtaining the desired surface quality of N6 grade. A prototype software for the visual measuring of the layer thickness in multi-layered metal materials has been developed and included in the process of determining the minimal required depth of cutting.

The following main conclusions can be drawn from the research:

- The ANN model is able to precisely predict the surface roughness $R_{\mathrm{a}}$ of deposited layers based on two LENS process parameters. 


\section{U. ŽUPERL et al.: MINIMUM DEPTH OF MILLING TO OBTAIN THE DESIRED SURFACE ROUGHNESS IN ...}

- The predicted $R_{\mathrm{a}}$ values are very close to the experimental values.

- The layer thickness has a significant influence on the minimum axial milling depth required to achieve the desired surface roughness.

- The developed thickness measurement software has a high layer-thickness measuring accuracy.

- Comparisons between the measured thicknesses of one deposited layer and those obtained experimentally show good agreement.

\section{REFERENCES}

${ }^{1}$ J. Y. Jeng, M. C. Lin, Mold fabrication and modification using hybrid processes of selective laser cladding and milling, Journal of Materials Processing Technology, 110 (2001) 1, 98-103, doi:10.1016/S0924-0136(00)00850-5

${ }^{2}$ S. Gopagoni, J. Y. Hwang, A. R. P. Singh, B. A. Mensah, N. Bunce, Tiley, J. R. Banerjee, Microstructural evolution in laser deposited nickel-titanium-carbon in situ metal matrix composites, Journal of Alloys and Compounds, 509 (2011) 4, 1255-1260, doi:10.1016/ j.jallcom.2010.09.208

${ }^{3}$ P. K. Farayibi, T. E. Abioye, J. W. Murray, P. K. Kinnell, A. T. Clare, Surface improvement of laser clad Ti-6Al-4V using plain waterjet and pulsed electron beam irradiation, Journal of Materials Processing Technology, 218 (2015), 1-11, doi:10.1016/j.jmatprotec.2014.11.035

${ }^{4}$ D. F. Susan, J. D. Puskar, J. A. Brooks, C. V. Robino, Quantitative characterization of porosity in stainless steel LENS powders and deposits, Materials Characterization, 57 (2006) 1, 36-43, doi:10.1016/j.matchar.2005.12.005

${ }^{5}$ D. G. Ahn, Applications of laser assisted metal rapid tooling process to manufacture of molding \& forming tools-state of the art, International Journal of Precision Engineering and Manufacturing, 12 (2011) 5, 925-938, doi:10.1007/s12541-011-0125-5

${ }^{6}$ U. Župerl, F. Čuš, T. Irgolič, Prediction of Cutting Forces in Ball-End Milling of Multi-Layered Metal Materials, Strojniski Vestnik/Journal of Mechanical Engineering, 62 (2016) 6, doi:10.5545/sv-jm e.2015.3289

${ }^{7}$ I. Tabernero, A. Calleja, A., Lamikiz, L. L. de Lacalle, Optimal parameters for 5-axis laser cladding, Procedia Engineering, 63 (2013), 45-52, doi:10.1016/j.proeng.2013.08.229
${ }^{8}$ A. Calleja, I. Tabernero, A. Fernández, A. Celaya, A. Lamikiz, L. L. De Lacalle, Improvement of strategies and parameters for multi-axis laser cladding operations, Optics and Lasers in Engineering, 56 (2014), 113-120, doi:10.1016/j.optlaseng.2013.12.017

${ }^{9}$ N. Zeroudi, M. Fontaine, Prediction of Machined Surface Geometry Based on Analytical Modelling of Ball-end Milling, Procedia CIRP (2012) 1, doi:10.1016/j.procir.2012.04.017

${ }^{10}$ W. H. Ho, J. T. Tsai, B. T. Lin, J. H. Chou, Adaptive network-based fuzzy inference system for prediction of surface roughness in end milling process using hybrid Taguchi-genetic learning algorithm, Expert Syst. Appl., (2009) 36-2, doi:10.1016/j.eswa.2008.01.051

${ }^{11}$ M. Z. Azlan, H. Haron, S. Sharif, Prediction of surface roughness in the end milling machining using Artificial Neural Network, Expert Systems with Applications, (2010), 37-2, doi:10.1016/j.eswa.2009. 07.033

${ }^{12}$ J. P. Costes, V. Moreau, Surface roughness prediction in milling based on tool displacements, Journal of Manufacturing Processes, (2011), 13-2, doi:10.1016/j.jmapro.2011.02.003

${ }^{13}$ M. Grzenda, A. Bustillo, The evolutionary development of roughness prediction models, Applied Soft Computing, (2013), 13-5, doi:10.1016/j.asoc.2012.03.070

${ }^{14}$ M. Dong, N. Wang, Adaptive network-based fuzzy inference system with leave-one-out cross-validation approach for prediction of surface roughness, Applied Mathematical Modelling, (2011) 35-3, doi:10.1016/j.apm.2010.07.048

${ }^{15} \mathrm{G}$. Samtaş, Measurement and evaluation of surface roughness based on optic system using image processing and artificial neural network, The International Journal of Advanced Manufacturing Technology, 73 (2014) 1-4, 353-364, doi:10.1007/s00170-014-5828-1

${ }^{16}$ M. Jurevicius, J. Skeivalas, R. Urbanavicius, Analysis of surface roughness parameters digital image identification, Measurement, 56 (2014), 81-87, doi:10.1007/s12541-014-0587-3

${ }^{17}$ S.M Sundarand, S. Raman, Analysis for vision assisted optical characterization of machined surfaces, Mfg Sci. Engng., 64 (1993), 43-58, doi:10.1016/s0007-8506(07)61366-3.

${ }^{18}$ M. Coman, S. D. Stan., M. Manic, R. Balan: Application of distance measuring with Matlab/Simulink. HSI 10, Proceedings of the $3^{\text {rd }}$ International Conference on Human System Interaction, 2010, 113-118, doi:10.1109/hsi.2010.5514581

${ }^{19}$ B. Jovanovič: Naprava za avtomatizirano kontrolo puš $=$ The device for automated control of bushes, Zbornik devete konference Avtomatizacija v industriji in gospodarstvu, Maribor, 2015, 1-7 